821.163.41.09:165.731 Поповић Павле 821.163.41.09 Петровић Његош Петар II https://doi.org/10.18485/msc.2019.48.2.ch5

Горан М. РАДОЊИЋ Универзитет Црне Горе Филолошки факултет
Оригинални научни рад Примљен: 12. 12. 2018. Прихваћен: 14. 02. 2019.

\title{
ПРИСТУП ПАВЛА ПОПОВИЋА ЬЕГОШЕВОМ ГОРСКОМ ВИЈЕНЦУ И ПОЗИТИВИЗАМ
}

\begin{abstract}
У раду се проблематизује мишљење критике да је приступ Павла Поповића Горском вијениу позитивистички. Уочавајући одређену обнову интересовања за позитивизам у нашем времену, разматрају се карактеристике позитивизма, и Поповићев приступ види као различит, али истовремено близак савременим теоријама које текст посматрају у друштвеном контексту, рецимо, новом историзму. За Поповића значење је у функционисању текста и у дјеловању текста у друштву, у првом плану су начини на које текст утиче на ставове и вриједности друштва. Речено на начин савремене теорије, Поповића занима како Његош конструише идентитет своје заједнице. Наглашава се Његошева политичка концепција, и она, по Поповићу, изазива поетску концепцију.

Кључне ријечи: Горски вијенаи, Павле Поповић, позитивизам, значење текста, Његошева политичка концепција.
\end{abstract}

Историја тумачења Његоша умногоме је и историја српске критике. Начин на који се Његошу приступа говори о разумијевању књижевности, о вриједностима, али и о култури и времену у ком су тумачења настајала. Траје истовремено и, некад јача, некад слабија, борба око Његоша - некад и дословно схваћено - борба за овладавање Његошем. Посебно је питање Његошевог канонског статуса, као и аспеката на основу којих он тај статус стиче, и одржава. У том погледу, карактеристична је напомена Велека и Ворена: „Сваки нараштај оставља у великом уметничком делу по нешто што не присваја, налази да су неке његове разине или слојеви мањкави у 'лепоти', па чак и сасвим ружни [...], али да оно, у целини, ипак естетски задовољава" (Велек и Ворен 1991: 288).

У том контексту може се посматрати и приступ Павла Поповића Његошевом Горском вијениу. Он је један од тумача какве описују Велек и Ворен, који ће високо цијенити Горски вијенац, а налазећи у том тексту и нешто што

*gmradonjic@yahoo.com 
је сматрао крупним мањкавостима. Нови увид у Поповићев приступ Његошу може указати на значај Поповића како за тумачење Његоша, тако и за нашу слику о развоју српске критике, а и уопште о науци о књижевности.

Поповић је започео бављење Његошем 1895. године (у часопису „Српски преглед"); студију $O$ Горском вијенцу штампао 1900. и 1901. у мостарској „Зори”, а као посебну књигу 1901. у Мостару, у поводу обиљежавања педесетогодишњице Његошеве смрти; наставља и касније, па пише текстове „Млади Његош”, „Петар II Петровић Његош у Бечу у годинама 1836-1837”, „Из 'Луче микрокозма'”, „Враз према Његошу” (в. Љубинковић 2000: 181).

Поповићева студија о Вијениу прештампава се, а 2000. године добили смо Сабрана дела Павла Поповића. То говори с једне стране о угледу, о једном трајном присуству, али и о својеврсном оживљавању интересовања за Поповића у наше вријеме - дакле, нека врста двострукости. У складу са тим, мијењала се и оцјена Поповићевог приступа и резултата.

Јован Деретић даје у Историји српске књижевности не баш повољну оцјену Павла Поповића. Најприје одређује врсту и предмет Поповићевих истраживања: „Његове књижевне студије имају троструку основу: архивска истраживања, која су му омогућавала да реконструише слике епоха и биографије писаца; компаративна проучавања, у којима је утврђивао везе домаће књижевности са другим литературама; и критичку анализу књижевних дела где су му узор Сент-Бев и други француски критичари 19. столећа." (Деретић 2004: 928). ${ }^{1}$

Примијетићемо ту да Деретић таутолошки дефинише компаративна проучавања. Је ли тај вишак рјечитости у једном сажетом приказу можда и знак избјегавања да се понуди права, рекли бисмо, објективна, оцјена? А Деретићева оцјена гласи:

У његовој методологији откривају се многе предности али и ограничења тих приступа. Он је позитивистички исувише заокупљен детаљем, тако да обично губи из вида целину, у књижевној анализи показује доста школске педантерије и формализма, понекад и личне загрижљивости, али му се не може оспорити осећање за вредности текста. У његовом излагању има козерске лежерности и фамилијарности, оно зна бити занимљиво, понекад духовито, али и пасти до необавезног ћаскања о тривијалним ситницама (928-929).

Кад то прочитамо, питамо се гдје су предности, јер поменуте су само мане - тешко да би се „осећање за вредности текста”, ма како оно било схваћено, могло узети као предност методологије, а тек то не могу бити „козерска лежерност и фамилијарност".

Да ли је ту укључена и нека лична димензија, поготово с обзиром на помињање „личне загрижљивости”, што такође не може бити дио метода? Из наше перспективе, можда је ипак неочекивано да Деретић свог великог претходника не посматра са мало више пажње и одмјерености.

\footnotetext{
${ }^{1}$ Узимам Деретићеве експлицитне ставове из Историје као његов сажето исказан поглед на свог претходника, имајући у виду да се, између осталог, монографија Композиција Горског вијенца може разумјети и као својеврсна полемика Деретића са Поповићем.
} 
Поповић је прилично лоше оцијењен, и то је проблематично, неправедно. Необично је да му је остала етикета „позитивисте”. Додуше, неки од разлога за повезивање са позитивизмом налазе се и код самог Поповића, рецимо, на декларативном нивоу, када објашњава свој метод. Један од разлога може бити и у томе што студију о Његошу закључује цитатом из Сент-Бева који управо говори о аналогији са читањем, са тумачењем, о дотицању дирки у намери да се проба звук, „и на све њих дух нашега песника одјекнуо је као какве силне, огромне оргуље” (Поповић 2000: 126). Проблем је, међутим, што та аналогија, па и сам стил, тешко да представља самог Поповића и његов приступ.

Помиње Поповић Сент-Бева, на пример, и када говори о важности радње, како Сент-Бев примјећује да ,радња често слаби код Г. Балзака” (58), те да критичари, међу којима је Сент-Бев, не би осудили стару грчку трагедију по томе што нема радње (59). Не улазећи у то колико бисмо се данас сложили са тим тумачењима, јасно је да Поповић наводи Сент-Бева као илустрацију својих теза, и као потврду општетеоријских ставова. Но, то је варљиво, јер једва да Деретићев опис може важити за Поповићеву студију $O$ Горском вијенцу.

У недавном раду, Ненад Николић примјећује како Поповић „учинио је отклон од дотадашњих приступа Горском вијениу и поставио његово проучавање на основе ближе самом тексту дела" (Николић 2014: 427). То би требало да значи да се Поповић приближава некој врсти иманентног приступа. Међутим, прихвата се и етикета „позитивисте” за Поповића, и то наводећи наслове поглавља из Поповићеве студије, који би сами по себи могли да буду аргумент управо против те етикете: „Организујући монографију кроз поглавља 'Грађа', 'Предмет', 'Радња', 'Карактери' и 'Дикција', Поповић је наговестио уобичајени пут позитивистичког истраживања" (429).

Поповићеви наслови сугеришу управо антипозитивистички приступ. Рекло би се да се он креће на трагу Аристотела, и појмови које ставља у први план карактеристични су за оно што Велек и Ворен називају „унутарњим проучавањем књижевности". Корисно је, онда, присјетити се основних карактеристика позитивизма, те његовог статуса у теорији књижевности.

Треба поновити: гријех „позитивизма” велики је гријех, и он је у схватању XX вијека учинио да великани и доминантне фигуре критике XIX вијека, какви су Сент-Бев или Вилхелм Шерер, постану маргинализовани. Они су маргинализовани толико да, нпр. у обимној Нортоновој антологији теорије и критике, са више од 2600 страница, не само да та двојица нису заступљени као аутори, него се ни не помињу ни у једном тексту, као ни сам појам позитивизма (види: Лич 2001). ${ }^{2}$

Посљедњих пар деценија долази до својеврсне обнове интересовања за позитивизам, рецимо за Сент-Бева, гдје се могу издвојити један број француског часописа Romantisme који му је посвећен, ${ }^{3}$ те један занимљив рад из

\footnotetext{
${ }^{2}$ Могло би се размишљати да ли је изостављање позитивизма посљедица мишљења да је он без значаја за савременост, или се ради о дјеловању специфичног, америчког контекста.

${ }^{3}$ Види: Romantisme, No. 109. Sainte-Beive ou l'invention de la critique, 2000.
} 
2010. године који упоређује теорије и методе Сент-Бева и Шерера (Калтенбрунер 2010).

Како формулише Калтенбрунер, критика Сент-Бевова је „критика која је покушавала да разумије књижевна дјела реконструишући биографије аутора и друштвену средину” (Калтенбрунер 2010: 75). ${ }^{4}$ За Сент-Бева узор су ботаника и компаративна анатомија. „Главно интересовање у Сент-Бевовом истраживању је заправо класификација појединца у психолошке породице или типове [...] за које су детерминистички биографски прикази појединачних портрета служили као база" (78, истакао аутор). Калтенбрунер наглашава како ће Сент-Бев чак признати „да његово интересовање за психолошку класификацију често претеже над интересовањем за књижевност per se" (Исто). Због тога се код Сент-Бева ,резервоар релевантних емпиријских извора за ову врсту антрополошког истраживања проширује са књижевних, приватних, и биографских докумената који се односе на појединачну особу на историјску свеукупност те врсте текстова" (Исто).

Ту су важна два момента: књижевност није циљ истраживања (циљ је наука о моралу); књижевност није повлашћен предмет, већ је књижевни текст у истој равни са другим текстовима.

Главне замјерке позитивизму, наравно, јесу да се не бави самим текстом, редукционизам, тј. свођење комплексног књижевног текста на мали број фактора, и то што каузалност сматра кључном релацијом, па завршава у релативизму и бављењу биографијом, друштвом и слично. Антипозитивистички заокрет почетком XX вијека одбацио је многе позитивистичке претпоставке, Међутим, неке особине чине позитивистички приступ сличним са неким каснијим теоријама. Тако, рецимо, идеје да се може објективно бавити текстом, да текст има цјеловито значење и да се до њега може доћи темељним истраживањем повезују позитивизам са наизглед супротним правцима као што су формализам или структурализам. Са друге стране, посматрање текста у контексту, прије свега у друштвеном контексту, приближава позитивизам теоријским правцима са краја XX и почетка XXI вијека, насталим у новом, културолошком заокрету.

У том смислу се могу разумјети оспоравања Поповића, када овај говори о нетачном и недовољном тумачењу у ранијој критици: „Разликовање нетачности и недовољности у дотадашњој критици о Горском вијениу, те са тим повезано тачније и пуније оцењивање, знак је да Поповић полази од позитивистичке претпоставке о апсолутном значењу књижевног дела" (Николић 2014: 428, истакао аутор). Ту је заправо у питању типично постструктуралистичко проблематизовање претпоставки не само позитивизма него, рецимо, и руског формализма, или англоамеричке нове критике, или структурализма, дакле свих праваца са којима позитивизам дијели увјерење о могућности објективног метода којим се долази до тачно одређеног значења.

\footnotetext{
${ }^{4}$ Аутор додаје да је Сент-Бев углавном писао за умјерене љевичарске часописе (Исто). То није без значаја.
} 
Могу се Поповићевом приступу Горском вијениу дати различите замјерке. Између осталих, недосљедност - неке сегменте, епизоде, узима као разумљиве на први поглед, док за друге проблематизује управо тај први поглед, први утисак. И на општем нивоу, Поповић сузбија тумачења по којима је у Горском вијениу у првом плану сликање живота и обичаја Црногораца, а афирмише тумачење по коме Његошево дјело карактерише јединство предмета, а то је истрага. Он, зато, све елементе и све епизоде тумачи с обзиром на ту општу идеју о јединству предмета, а то му је и критеријум на основу кога вреднује и сам Горски вијенаи и његову композицију. Како каже Николић, „Поповићу је стало да покаже да је предмет Горског вијенияа јединствен и да је у њему све у вези са истрагом потурица" (Николић 2014: 431). Николић напомиње да Поповић говори о значају и јединству истраге, смислу који je, по Поповићу, у њему видио Његош, „,а који је Поповићева претпоставка целовитог смисла Горског вијенца, јер се не изводи из Његошевих мемоара или неких сличних докумената, већ истог оног дела које се интерпретира" (Исто, истакао аутор).

По том аспекту, можемо рећи, Поповић се издваја и од позитивизма, а и од савремених проучавања у којима је примјетна тежња да књижевни текст изгуби повлашћено мјесто и да се текстови из разних (свих) сфера третирају једнако.

То је важан моменат - питање гдје је смисао текста и које све елементе и релације Поповић узима у обзир. За Поповића значење је у функционисању текста и у дјеловању текста у друштву.

Поповић претпоставља јединство предмета као кључну карактеристику текста. Може се поставити питање колико је та идеја о јединству предмета блиска новокритичарској идеји о органском јединству текста? Можда се може отићи и корак даље, па Поповићеву претпоставку видјети и као надовезивање на идеју Е. А. Поа да текст треба да има јединство утиска (в. По 1991). Са друге стране, Т. С. Елиот истиче да то не мора да важи, да се ради о Поовом уопштавању сопствене поетике, као што је, уосталом и идеја да не мора бити јединства утиска уопштавање Елиотове поетике. „Ниједан песник, када пише властиту art poétique, не треба да се нада да ће учинити много више него објаснити, рационализовати, одбранити или припремити пут за сопствену праксу: то јест за писање сопствене врсте поезије”, каже Елиот. „Он може мислити да установљава законе за читаву поезију; али оно што он говори и што је вредно казивања има своју непосредну везу са начином на који он сам пише или жели да пише" (Елиот 1975: 297).

Уз модификације, Елиотов став могао би се примијенити на читаоца, теоретичара и критичара - и он рационализује и уопштава, тј. елементима које воли у неким књижевним текстовима придаје универзалност, или, прецизније, тумачењима тих елемената даје значај општетеоријских ставова.

У Поповићевом тумачењу Горског вијениа настаје колизија између априорног мишљења да текст треба да има јединство предмета и високог вредновања Његошевог текста који не функционише у складу са тим правилом. Поповић настоји да то превлада, како би могао Горски вијенаи истовремено да 
сматра „најлепшим делом наше књижевности” (Поповић 2000: 57) и дјелом чија „композиција одиста не ваља” (48). Понудиће различита објашњења, „за утеху, пак, нама свима који волимо Његоша" (48): да и Шекспир гријеши, да није мана што радња није развијена, да Његош није ни хтио радњу (види: 48, 57-66). Једино што неће понудити је изградња другачије теорије, а она, заправо, није далеко - кад би „предметом” сматрао не радњу, него, рецимо, тематику, Поповић би се заправо приближио ономе како ће Деретић тумачити Горски вијенаи.

Наводећи Аристотелову концепцију трагедије, по којој је прича, како Деретић каже, „главни обликотворни принцип”, Деретић истиче да у Горском вијениу „уместо приче у први план долази говор личности”, као и „главна садржина тог говора: песничка мисао, dianoia” (Деретић 1996: 140). Затим се позива на Нотропа Фраја, по коме је Аристотелов термин dianoia „најбоље превести термином тема", као и на Бориса Томашевског, који говори о дјелима „без сижеа” (Исто). Тиме отвара могућност за сасвим другачије вредновање композиције Горског вијенияа.

Можемо парадоксалност у Поповићевом схватању књижевности и вредновању Горског вијенца разумјети као недостатак способности да на другачији начин види кохеренцију текста. Али, тако бисмо могли тражити и да одбаци идеју кохеренције, и да буде у складу са идејом Шкловског, који, са искуством футуризма, тврди да је Стернов Тристрам Шенди „најтипичнији роман свјетске књижевности” (види: Шкловски 1969). Павле Поповић, међутим, није развијао свој укус на модернизму. Може се, зато, разумјети и другачије, управо као врлина Поповићева, да упркос сопственој концепцији књижевности највише вреднује књигу која се у ту концепцију не уклапа.

У сваком случају, бавећи се питањима композиције, и на такав начин, Поповић се јасно одваја од позитивистичког приступа.

Важна димензија Поповићевог приступа јесте у томе што он Горски вијенаи разматра у друштвеном контексту. То не чини на позитивистички начин, тако што би тражио биографске или друштвене узроке настанка текста. Напротив, он испитује дјеловање текста на друштво, и налази да је то кључни текст за формирање једне заједнице. Речено на начин савремене теорије, Поповића занима како Његош конструише идентитет своје заједнице.

Поповић наглашава карактер централног догађаја: „Кад се узме у поређење Црна Гора пре истраге потурица и Црна Гора после ње, види се да је догађај Бадњега вечера учинио у њој огроман прелом. Пре тога догађаја, Црна Гора не представља један народ него једну гомилу племена, гомилу братстава, без везе међусобне, без идеје заједничке. [...] Речју, пре истраге, Црна Гора не представља државу, Црногорци не представљају народ” (Поповић 2000: 24).

Догађај чини да бива оно што је било немогућно један или два вијека раније: „братства којима су поклани потурчењаци, не бране своје потурчењаке него, напротив, одобравају покољ њихов, зато што је учињен у име вере и државе (то је двоје онда заједно ишло). Ту је први пут државна идеја надјачала осветољубивост братстава. Ту први пут сепаратизам пропада а народна 
мисао се помаља као идеја водиља. Ту се први пут Црногорци сједињују у један народ и Црна Гора у једну државу” (Исто). За Поповића, истрага потурица је „важнија од сваке победе”, а „револуција Бадњега Вечера препородила и ујединила народ. Истрага је, дакле, јединствен догађај у црногорској историји. Како још она представља прво ослобођење Срба од Турака, век раније од онога у Србији, то је она јединствен догађај и у историји целог српског народа" (24-25).

За Поповића пресудна је Његошева политичка концепција: „У оном месном боју који је црногорска историја једва забележила, он је видео један од најкрупнијих догађаја наше народне историје. У ослобођењу оног маленог краја црногорског [...] он је видео ослобођење целога Српства. Такву је важност Његош давао истрази потурица. То је његова политичка концепција догађаја" (25).

Поповићево тумачење важно је и као теоријски принцип:

Политичка концепција изазвала је код Његоша поетску концепцију догађаја. Кад је овако незнатни бој замислио као велики историјски догађај, Његош је и све оно што се на бој односило замислио у размјерама ширим но што их је овај у ствари имао. Он је од њега начинио један рат, један свети и неизбежни рат, који цела земља тражи, за којим цео народ вапије. Он је једну личну идеју владике Данила претворио у општу тежњу целог црногорског народа. Он је ону смелу операцију онаквог увиђавног политичара као што је био Данило, увећао у једнодушну националну манифестацију целе Црне Горе. Он је представио моменат истраге као моменат кад сви Срби осећају да им треба коначно поделити Косово с Турцима, кад је крвца проврела из земље и кад је, ако је икад, дошао земан да се воjyje (25).

Поповић као примарни види политички аспект, а при описивању се служи сликама из „Почетка буне против дахија”. Несумњиво је да он има у виду и сопствени политички контекст, јер говори у ситуацији када убрзо долази исто такво вријеме - да се коначно подијели Косово са Турцима, тј. долази доба Балканских ратова и Првог свјетског рата, ослобођења и уједињења. Како каже Љубинковић: „Књижевно дело које на особен начин говори о проблемима настајања и утемељивања државе и слободе било је управо идеално примерено историјском тренутку у коме је и Павле Поповић учествовао, коме је и сам сведочио" (Љубинковић 2000: 181).

Ту се поново потврђује (Гринблатова, и не само његова) теза да, говорећи о проблемима, опсесијама и противрјечностима неког ранијег времена, заправо говоримо о свом времену и о себи. Поповић је, дакле, веома одређен контекстом у коме се бави књижевношћу и са̂м са јасним идеолошким и политичким циљевима. И то не само у овој студији.

За Поповићев приступ, а и за тумачење Горског вијенияа, важан је и став који, полемишући са И. Руварцем, Поповић исказује једним декларативним тоном, као да се ради о судској изјави: „сматрам за потребно изјавити да се $[\ldots]$ мене ни најмање не тиче права историјска истина о догађајима. Могу сви догађаји о којима је у овој расправи реч бити потпуно измишљени, моје расправљање неће тиме ништа изгубити. Ја пратим овде само Његошево схватање и познавање историје а не испитујем саму историју” (25н). 
Поповић јасно прави разлику између књижевности и историје, тј. између фикције и стварности. У први план ставља дјеловање текста на читаоце, на заједницу којој је упућен, и то дејство прије свега види у политичкој сфери; текст, рекло би се терминима савремене теорије књижевности, конструише стварност тако што аутор преговара са друштвеним институцијама и праксама; ${ }^{5}$ из те политичке, идеолошке функције текста проистичу његове остале особине, оно што Поповић назива „поетска концепција догађаја”.

Поповићев приступ има додира са позитивистичким утолико што узима у обзир фукнционисање текста у друштвеном контексту. Али, код њега је приступ сасвим супротног смјера од позитивизма, и то га чини блиским, рецимо, перспективи новог историзма. У позитивистичком виђењу примарна је каузалност, траже се узроци за настанак дјела, фактори који дјелу претходе. За Поповића примарно је дјеловање текста на читаоче, начини на које он утиче на ставове и вриједности друштва.

Јавља се и питање вредновања. И, тим поводом, и шире питање, о начинима на које вреднујемо и факторима који на то утичу.

И ту се може сагледати Поповићев рад на различите начине. Николић сматра да Поповић, „у ствари, само тражи начин да потврди високу оцену која анализи претходи" (Николић 2014: 436), а Поповићеве интерпретације су „пресудно условљене нормативном поетиком која тражи јединство предмета, композиције и радње" (435, истакао аутор). Затим закључује да је „књижевна критика подређена суду културе; култура, која је Горски вијенаи високо вредновала, не допушта да литерарна анализа пронађе да је то дело слабо. У том раскораку између оцене културе и књижевне критике, отворен је простор за културолошко питање о Горском вијениу, које би требало да осветли разлоге његовог високог места и српској култури" (436-437, истакао аутор). Из тога произлази и општи суд о интерпретацији да би се „могло рећи да је не само свака интерпретација подређена нормативној поетици, већ и да је целокупна књижевна анализа подређена културом и традицијом условљеној представи о врхунској вредности Горског вијенц̧а" (437).

Поставља се питање колико је та представа о врхунској вриједности Горског вијенца утемељена у традицији у вријеме када Павле Поповић пише своје текстове о Његошу.

Сјетимо се Историје српске књижевности Стојана Новаковића, њеног „другог, сасвим прерађеног издања” из 1871. године. Ту Новаковић каже за Горски вијенаи да ће „остати као вечити спомен појетскога дара неумрлога владике црногорског” (Новаковић 1871: 285). Он истиче да Његош и Бранко Радичевић имају преломни значај, упоређује их, и даје предност Радичевићу: „Покрај песничке самосталности једнаке с владичином Бранко га надвишује уметничком страном својих песама, финоћом и лакошћу, која је у његовим песмама ненадмашна" (286). Овдје можемо по страни да оставимо критеријуме Новаковићеве, али нам тај став говори како у то вријеме Његошев ка-

\footnotetext{
${ }^{5}$ Гринблат каже: „Умјетничко дјело производ је преговарања између творца или класе твораца, опремљених комплексним репертоаром конвенција које као заједница дијеле, и друштвених институција и пракси“ (Гринблат 2005: 28).
} 
нонски статус није стабилан и неспоран. Можда би се прије могло рећи да је „у Поповићево време Његош још увек био тек условно признат и прихваћен” (Љубинковић 2000: 184). Канонски статус Његошев учврстиће се само коју деценију касније, заслугом, између осталих (или, прије свега), Павла Поповића, и, рецимо, Скерлића. Скерлић ће за Горски вијенаи у Историји нове српске књижевности дати готово као констатацију: „Тај најбољи спев српске књижевности у исти мах је и најпопуларнија, највише издавана и најчитанија српска књига" (Скерлић 1967: 188).

Ту Скерлић мисли на књигу уопште, не само на књижевна дјела, а тиме не изједначава различита писања него афирмише књижевност као врхунски тип текста.

Из данашње перспективе чини се да је значај Поповићеве студије $O$ Горском вијенцу велики. Поповић додирује многа важна питања, и можемо разна његова запажања и ставове разумјети и као повод да поново размислимо о Његошу. Притом, што није и без једне општетеоријске консеквенце, Поповић је подстицајан можда управо зато што није био досљедан у свом приступу. Другим ријечима, што је био у стању да сагледа Његоша из разних перспектива, па и из оних које ће теорија књижевности открити много касније, након више деценија.

\section{ЛИТЕРАТУРА}

Велек и Ворен 1991: Р. Велек, О. Ворен, Теорија књижевности, Београд: Нолит. Превели Александар И. Спасић, и Слободан Ђорђевић.

Гринблат 2005: S. Greenblatt, The Greenblatt Reader, Malden, MA: Blackwell Publishing. Edited by Michael Payne.

Деретић 1996: Ј. Деретић, Композиција Горског вијенца, Подгорица: Октоих. Деретић 2004: Ј. Деретић, Историја српске књижевности, Београд: Просвјета. Елиот 1975: T. S. Eliot, „Od Poa do Valerija”, u: Rađanje moderne književnosti: poezija, Sreten Marić, Đorđije Vuković (prir.), preveo Dušan Puvačić, Beograd: Nolit, 294-303.

Калтенбрунер 2010: W. Kaltenbrunner, “Literary Positivism? Scientific Theories and Methods in the Work of Saint-Beuve (1804-1869) and Wilhelm Scherer (1841-1886)", Studium, 3, 74-88.

Лич 2001: V. B. Leitch (ed.), The Norton Anthology of Theory and Criticism, New York: Norton.

Љубинковић 2000: Н. Љубинковић, „Павле Поповић о Његошу”, у: Поповић 2000: 179-187.

Николић 2014: Н. Николић, „Павле Поповић о Горском вијениу: традиција, позитивизам и интерпретација", у: Научни састанак слависта у Вукове дане, 43, Његош у своме времену и данас, 2/43. научни састанак слависта у Вукове дане, Београд, 12-15. IX 2013, Београд: Међународни славистички центар, 427-438. 
Новаковић 1871: Стојан Новаковић, Историја српске књижевности: преглед угађан за школску употребу: с једним литографским снимком, Београд: Издање и штампа државне штампарије.

По 1991: E. E. Po, „Filozofija kompozicije”, u: Petar Milosavljević, Teorijska misao o književnosti, Novi Sad: Svetovi, 206-214. Preveo Božidar Marković.

Поповић 2000: П. Поповић, Сабрана дела, књ. VIII, О Његошу, Београд: Завод за уџбенике и наставна средства. Приредио Ненад Љубинковић.

Поповић 2000а: П. Поповић, О Горском вијенцу, у: Поповић 2000: 1-137.

Скерлић 1967: Ј. Скерлић, Сабрана дела, књ. 13, Историја нове српске књижевности, Беорад: Просвета. Приредио Мидхат Бегић.

Шкловски 1969: V. Šklovski, Uskrsnuće riječi, preveo Juraj Bedenicki, Zagreb: Stvarnost.

Romantisme, No. 109. Sainte-Beive ou l'invention de la critique, 2000.

\author{
Goran Radonjić
}

\title{
PAVLE POPOVIĆ'S APPROACH TO THE MOUNTAIN WREATH BY NJEGOŠ AND LITERARY POSITIVISM
}

\section{(Summary)}

This paper re-examines Pavle Popović's approach to Njegoš's Mountain Wreath. It is an established view of criticism that Popović's approach is a positivist one. After considering some of the characteristics of literary positivism, and comparing them with those of Popović's study On The Mountain Wreath, his approach is regarded as closer to some of the recent theories which interpret literary text in social context, namely the New Historicism. For Popović, the meaning of the text is in its functioning within itself, as well as in its functioning in society. He focuses on the ways the text shapes social attitudes and values. In the terms of recent criticism, Popović is interested how Njegoš constructs identity of his community. Njegoš's political conception is foregrounded, and, according to Popović, it induces Njegoš's poetic conception. 